\title{
Physicochemical Standardization of Polyherbal Powder Formulation: Safoof-e-Makhana
}

\author{
Gazi Jahangeer Rather, Hamiduddin*, Mohd Ikram, Shaista Fatima, MD Naquibuddin
}

\section{Gazi Jahangeer Rather, Hamiduddin*, Mohd Ikram, Shaista Fatima, MD Naquibuddin}

Department of Ilmul Saidla (Unani Pharmacy), National Institute of Unani Medicine (NIUM), Bangalore-560091, Karnataka, INDIA.

Correspondence

Dr. Hamiduddin

Lecturer, Department of IImul Saidla (Unani Pharmacy), National Institute of Unani Medicine (NIUM), Kottigepalya, Magadi Main Road, Bangalore 560091, Karnataka, INDIA.

Phone no : 8088739927,9035109537

E-mail: drhamid2003@rediffmail.com

History

- Submission Date: 21-03-2018;

- Review completed: 16-05-2018;

- Accepted Date: 22-06-2018

DOI : 10.5530/pj.2018.5.151

Article Available online

http://www.phcogj.com/v10/i5

\section{Copyright}

(C) 2018 Phcog.Net. This is an openaccess article distributed under the terms of the Creative Commons Attribution 4.0 International license.

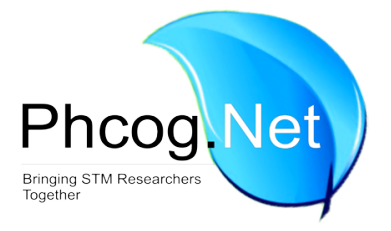

\begin{abstract}
Introduction: Safoof-e-Makhana (SM) is a Unani polyherbal powder formulation used to treat Sexual disorders. Formulation consists of following herbs Orchis latifolia, Hygrophila auriculata, Asparagus racemosus and Elettaria cardamomum. The main aim of this study was to standardize Safoof-e-Makhana (SM), on the basis of organoleptic characters and physico-phytochemical analysis. Methods: The drugs were cleaned, dried in shade and powdered by passing through sieve \# no. 80 as per the method described in UPI / National Formulary of Unani Medicine. This Safoof formulation was evaluated using physicochemical tests: powder characterization, extractive value, alcohol and water soluble matter, Ash value, LOD at $105^{\circ} \mathrm{C}, \mathrm{pH}$ and $\mathrm{HPTLC}$ fingerprinting. Statistical analysis used: Mean \pm SEM. Results: Organoleptic characters of the formulation are light brown colour, characteristic odour, sweet taste and moderately fine texture. Physicochemical parameters displayed water soluble extractive (21.83 \pm 0.08$)$, alcohol soluble extractive $(7.87 \pm 0.09)$, total ash $(4.76 \pm 0.08)$, acid insoluble ash $(3.36 \pm 0.01)$, water soluble ash $(0.89 \pm 0.25), \mathrm{LOD}$ at $105^{\circ} \mathrm{C}(11.38 \pm 0.34), \mathrm{pH}$ of $1 \%$ and $10 \%$ solution were 6.6 \pm 0.1 and $6.0 \pm 0.1$ respectively. Phytochemical qualitative analysis displayed presence of alkaloids, tannins, flavanoids, steroids, terpenoids, carbohydrates, volatile oil. HPTLC fingerprinting data was also set in. Conclusion: The standardization of this formulation was done and the data obtained would be used as a standard for future reference.

Key words: Physicochemical, Polyherbal, Powder, Formulation, Standardization, Safoof-eMakhana, Unani Medicine.

Key messages: Standardization of herbal drugs is very important for quality control. It improves the safety and efficacy of drug to provide the best possible medicine to the society. Obtained data for Safoof-e-Makhana will be useful as standards for quality control of formulation.
\end{abstract}

\section{INTRODUCTION}

Standardization of herbal formulations is essential in order to assess quality, purity and efficacy of drugs. The quality assessment of herbal formulations is of great importance in order to justify their acceptability in contemporary period of medicine. ${ }^{1}$ One of the major problems faced by the herbal industry is the unavailability of strict quality control measures for herbal medicines and their formulations. The World Health Organization (WHO) has appreciated the role and importance of medicinal plants for public health care in developing nations and has evolved guidelines to support the member countries in their efforts to formulate national policies on traditional medicine and to study their potential usefulness including evaluation, safety and efficacy. ${ }^{2}$ There is a tremendous role and scope in Indian traditional medicine including Unani system of medicine (USM) for production of standardized, therapeutically effective formulations. There is a need to explore the medicinally important plants and their formulations. This can be achieved only if the herbal products are analysed and evaluated using sophisticated modern techniques of standardization. ${ }^{3}$ Quality evaluation of herbal preparation is a fundamental requirement of pharmaceutical industry and other organization dealing with Unani and herbal products.

Safoof-e-Makhana (SM) is a polyherbal powder formulation used in the Unani System of Medicine for treatment of sexual disorders since ancient time and the formulation is mentioned in National Formulary of Unani Medicine. ${ }^{4}$ This formulation is not evaluated for its physicochemical and phytochemical standardization since yet as revealed by the literature survey. Thus keeping this goal in mind, the present study was carried out to fix the quality control standards of Safoof-e-Makhana (SM) with scientific analytical techniques.

\section{MATERIALS AND METHODS}

\section{Procurement of raw drugs}

Ingredients of Safoof-e-Makhana (SM) were procured from the pharmacy of NIUM and authentic shop of Bangalore, Karnataka, India. The identification of these drugs was done by the experts at National Institute of Unani Medicine Kottigepalya, Bangalore. 
The ingredients of Safoof-e-Makhana (SM) viz. Orchis latifolia Linn. (SalabMisri), Hygrophila auriculata (Schum.) Haine (Tukhm-e-Talmakhana), Asparagus racemosus willd.(Satawar) and Elettaria cardamomum Maton.(Ilaichi Khurd) are present in equal proportion.

\section{Preparation of Formulation}

All the drugs were first cleaned and dried in shade and powdered by passing through sieve \# no. 80. The formulation [Figure 1] was prepared as per the method described in UPI / National Formulary of Unani Medicine. $^{4}$

\section{Organoleptic evaluation}

The Organoleptic evaluation refers to evaluation of the Safoof-e-Makhana (SM) formulation by colour, odour, taste, appearance, particle size and texture. $^{5}$

\section{Powder characterization ${ }^{6-7}$}

Angle of Repose: The angle of repose gives an indication of the flow ability of the substance. Funnel was adjusted such that the stem of the funnel lies $2 \mathrm{~cm}$ above the horizontal surface. The drug powder was allowed to flow from the funnel under the gravitational force till the apex of the pile just touched the stem of the funnel, so the height of the pile was taken as $2 \mathrm{~cm}$. Drawing boundary along the circumference of the pile and taking the average of six diameters determined the diameter of the pile. These values of height and diameter were then substituted in the following equation:

Angle of Repose $(\theta)=\tan -1[2 \mathrm{~h} / \mathrm{d}]$

Where, $\mathrm{h}$ - Height of the pile and $\mathrm{d}$ - Diameter of the pile

The experiment was done in triplicate.

Bulk Density and Tapped Density: The weighed quantity (20 gm) of Safoof-e-Makhana (SM) is carefully put into a measuring cylinder without any losses. The initial volume was noted and the sample was then tapped until no further reduction in volume was noted. The initial volume gave the bulk density value and after tapping the volume gives the value of tapped density.

Carr's Index: Carr's index has been used as an indirect method of quantifying powder flow ability from bulk density; this method was developed by Carr. The percentage compressibility of a powder is a direct measure of the potential powder arch or bridge strength and stability, and is calculated according to following equation. Carr's index (\% compressibility $)=100 \times(1-\mathrm{Db} / \mathrm{Dt})$ Where Db $=$ Bulk density, Dt $=$ Tapped density

Hausner's Ratio: Hausner ratio has been also used as indirect method of quantifying powder flowability from bulk density. Hausner ratio $=\mathrm{Dt} / \mathrm{Db}$. Where $\mathrm{Db}=$ Bulk density and $\mathrm{Dt}=$ Tapped density.

\section{Physico-chemical evaluation}

The Physico-chemical evaluation of prepared Safoof-e-Makhana (SM) was done by testing loss of weight on drying at $105^{\circ} \mathrm{C}$, total ash, acid insoluble ash, water soluble ash, $\mathrm{pH}$ of $1 \%$ and $\mathrm{pH}$ of $10 \%$ solution and extractive values.

\section{Loss on drying at $105^{\circ} \mathrm{C}$}

An accurately weighed $3 \mathrm{~g}$ of Safoof-e-Makhana (SM) was taken in a petri dish. The crude drug was heated at $105^{\circ} \mathrm{C}$ in an oven till a constant weight and percentage moisture content of the sample was calculated with reference to the weighed Safoof-e-Makhana (SM) sample. ${ }^{8}$

Ash Values, Determination of total ash acid, insoluble ash, water soluble ash is done as per protocol for testing of ASU drug and UPI ${ }^{5,8}$

\section{Determination of $\mathrm{pH}$}

$1 \%$ and $10 \%$ solution of Safoof-e-Makhana (SM) was prepared in distilled water $(\mathrm{w} / \mathrm{v})$ and $\mathrm{pH}$ was determined by using digital $\mathrm{pH}$ meter. ${ }^{9}$

\section{Extractive values ${ }^{8}$}

Water soluble extractives: Five grams of Safoof-e-Makhana (SM) was macerated with $100 \mathrm{ml}$ of water in closed conical flask for $24 \mathrm{~h}$, shaken frequently for the first $6 \mathrm{~h}$ and allowed to stand for $18 \mathrm{~h}$. This was filtered through filter paper. Twenty-five millilitres of the filtrate was evaporated to dryness in petri dish, dried at $105^{\circ} \mathrm{C}$, and weighed. Percentage of water soluble extractive with reference to air-dried material was calculated.

Alcohol soluble extractives: Five grams of Safoof-e-Makhana (SM) was macerated with $100 \mathrm{ml}$ of $70 \%$ ethanol in a closed conical flask for $24 \mathrm{~h}$, shaken frequently during the first $6 \mathrm{~h}$, and allowed to stand for $18 \mathrm{~h}$. This was filtered rapidly taking precaution against loss of ethanol. Twenty five millilitres of the filtrate was evaporated to dryness in a petri dish, dried at $105^{\circ} \mathrm{C}$, and weighed. Percentage of alcohol soluble extractive was calculated with reference to air-dried drug.

\section{Successive extractive value and Non-Successive extractive value ${ }^{10}$}

Successive extractive value: The coarse powder of Safoof-e-Makhana (SM) was extracted successively using soxhlet apparatus with different solvent, in increasing order of polarity, petroleum ether $\rightarrow$ benzene $\rightarrow$ chloroform $\rightarrow$ ethanol. $10 \mathrm{~g}$ powdered drug was taken and subjected to successive extraction with each solvent for $6 \mathrm{~h}$. After that the extracts were filtered first by using filter paper (Whatman No. 1) and dried on water bath. The extractive values were determined with reference to the weight of the drug taken $(\mathrm{w} / \mathrm{w})$. The procedure was repeated 3 times to calculate mean extractive values.

Non successive extractive value: The coarse powder of Safoof-eMakhana (SM) was extracted separately in different solvent (water, ethyl alcohol and petroleum ether) using soxhlet apparatus. $10 \mathrm{~g}$ powdered drug was taken and subjected to separate extraction with each solvent. The extracts were filtered first by using filter paper (Whatman No. 1) and

\section{Table 1: Powder characterization of Safoof-e-Makhana.}

\begin{tabular}{ccc}
\hline S.no. & Parameters & Percentage mean $(\mathrm{n}=3) \pm$ SD \\
\hline 1. & Bulk Density $(\mathrm{gm} / \mathrm{ml})$ & $0.4442 \pm 0.0001$ \\
2. & Tapped Density $(\mathrm{gm} / \mathrm{ml})$ & $0.4876 \pm 0.0001$ \\
3. & Carr's index & $8.8876 \pm 0.0008$ \\
4. & Hausner's Ratio & $1.0974 \pm 0.0001$ \\
5. & Angle of Repose & $36.49^{\ominus} \pm 0.22$ \\
\hline
\end{tabular}

Table 2: Physicochemical characteristics of Safoof-e-Makhana.

\begin{tabular}{ccc}
\hline S.no. & Parameters & Percentage mean $(\mathbf{n}=3) \pm$ SD \\
\hline 1. & Loss on drying (\%) & $11.38 \pm 0.34$ \\
2. & Ash Content & \\
A & Total Ash (\% w/w) & $4.76 \pm 0.08$ \\
B & Water soluble Ash (\% w/w) & $0.89 \pm 0.25$ \\
C & Acid Insoluble Ash (\% w/w) & $3.36 \pm 0.01$ \\
3. & $\mathrm{pH}$ & \\
$\mathrm{A}$ & $\mathrm{pH}(1 \%)$ & $6.6 \pm 0.1$ \\
$\mathrm{~B}$ & $\mathrm{pH}(10 \%)$ & $6.0 \pm 0.1$ \\
\hline
\end{tabular}


Table 3: Successive Extraction and Non-Successive Extraction.

\begin{tabular}{cccccccccc}
\hline & \multicolumn{4}{c}{ Successive extractive value $(\% w / w)$} & \multicolumn{4}{c}{ Non-Successive extractive value(\%w/w) } \\
\hline Mean \pm SEM & Petroleum ether & Benzene & Chloroform & Ethanol & Petroleum ether & Benzene & Chloroform & Ethanol & Water \\
& $11.47 \pm 0.17$ & $0.57 \pm 0.09$ & $0.54 \pm 0.05$ & $2.27 \pm 0.09$ & $11.69 \pm 0.11$ & $9.02 \pm 0.05$ & $9.55 \pm 0.04$ & $12.90 \pm 0.05$ & $32.08 \pm 0.06$ \\
\hline
\end{tabular}

Table 4: Phytochemical Screening (Qualitative Estimation) of Safoof-e-Makhana.

\begin{tabular}{cc}
\hline Parameters & Result \\
\hline Alkaloids & + \\
Glycosides & + \\
Tannins & + \\
Steroids & + \\
Flavanoids & + \\
Sugars & + \\
Phenols & + \\
Proteins & + \\
Saponins & + \\
Resins & + \\
Terpenoids & + \\
Anthraquinones & + \\
Essential oils \& Fatty acids & + \\
\hline
\end{tabular}

evaporate on water bath. Extractive values were determined with reference to drug taken $(\mathrm{w} / \mathrm{w})$.

\section{Qualitative Estimation of constituents}

Qualitative estimation Safoof-e-Makhana (SM) for organic constituent's viz. alkaloids, glycosides, tannins, flavonoids, sugars, saponins, phenols, proteins, resins and steroids was done. ${ }^{9}$

\section{HPTLC fingerprinting analysis}

The weighed quantity ( $5 \mathrm{~g}$ ) of Safoof-e-Makhana (SM) was extracted in a Soxhlet apparatus for $6 \mathrm{~h}$ using $100 \mathrm{ml}$ of solvent (ethanol) at a controlled temperature. HPTLC was performed on $20 \mathrm{~cm} \times 10 \mathrm{~cm}$ aluminium backed plates coated with silica gel 60F254 (Merck, Mumbai, India). Standard solution of sample solution were applied to the plates as bands by use of a Camag (Muttenz, Switzerland) Linomat V sample applicator equipped with a $100 \mu \mathrm{l}$ Hamilton (USA) syringe. Ascending development to a distance of $80 \mathrm{~mm}$ was performed at room temperature $\left(28 \pm 2^{\circ} \mathrm{C}\right.$ in two different mobile phases separately viz. n-Butanol: Acetic acid: water (5:1:4) and Toluene: Ethyl acetate: Formic acid (5:4:1) (v/v), in a Camag glass twin-trough chamber previously saturated with mobile phase vapour for $20 \mathrm{~min}$. After development, the plates weredried and then scanned at $254 \mathrm{~nm}$ and $366 \mathrm{~nm}$ with a Camag TLC Scanner with WINCAT software, using the deuterium lamp. ${ }^{11}$

\section{RESULTS}

The organoleptic properties of Safoof-e-Makhana showed the colour was light brown, odour was characteristic, taste was sweet, texture was fine and particle size was $80 \#$. The powder characterization of Safoofe-Makhana is depicted in [Table 1]. The physicochemical Evaluation of Safoof-e-Makhana is mentioned in [Table 2] and water and alcohol soluble extractive values were found to be $\mathbf{2 1 . 8 3} \pm \mathbf{0 . 0 8}(\% \mathrm{w} / \mathrm{w})$ and 7.87 $\pm \mathbf{0 . 0 9}(\% \mathrm{w} / \mathrm{w})$ respectively. Successive and Non-Successive extraction,
Phytochemical Screening and HPTLC of Safoof-e-Makhana (SM) is depicted in Table 3, 4 and 5, 6, 7, 8 respectively.

\section{DISCUSSION}

Herbal formulations are considered harmless traditionally and being consumed increasingly by people without prescription. However, some can cause health problems, some are ineffective and some may interact with other drugs. Standardization of herbal formulations is essential in order to assess the quality and purity of drugs, based on the concentration of their active principles. ${ }^{13}$

Standardization is an important measure for knowing the quality, purity and for sample identification. It is essential for the correct identity of the materials.

Standards for Safoof-e-Makhana (SM) was generated in this work. Finished product of Safoof-e-Makhana (SM) was light brown in colour as per colour chart (No. PMS 141 of Panton color chart).$^{14}$ sweet in taste, characteristic in odor and without any clumping and aggregation.

The mean values of bulk density, tapped density, angle of repose, Hausner's ratio and compressibility index were $0.4442 \pm 0.0001,0.4876 \pm 0.0001$, $36.49^{\theta} \pm 0.22,1.0974 \pm 0.0001$ and $8.8876 \pm 0.0008$ respectively. Powder charecterrization methods i.e. Hausner's ratio and compressibility index are the simple and popular method to determine the flow characteristics of powder. The flow characteristics of powder depend on the size, shape and size distribution of particles. ${ }^{15}$ The compressibility index of Safoof-eMakhana (SM) lies below 10 according to the scale of flowbility, it shows the test drug SM has a excellent flow character. The Hausner's ratio of Safoof-e-Makhana (SM) lies in between 1.00 - 1.11, it indicates excellent flowbility. ${ }^{16-17}$ Angle of repose displayed Passable flow property. ${ }^{17}$ [Table 1]. The mean percentage of loss of weight on drying of Safoof-e-Makhana $(\mathrm{SM})$ is $11.38 \pm 0.34$. [Table 2] It is mentioned that the water content in plant drugs can vary between $8 \%$ and $14 \%$. The presence of excessive amount of moisture in plant drugs causes hydrolysis of constituents, growth of bacteria and fungi and biochemical reactions. The pharmacopoeial monographs compulsorily limit for the water content, especially in drugs that have hygroscopic nature, or in which the excessive amounts of water causes deterioration of products. ${ }^{18}$ The formulation having less amount of moisture can be expected to be safe for longer time.

The ash value is an important parameter in the quality control of herbal drugs. A high ash value is indicative of contamination, substitution, adulteration, or carelessness in preparing the drug or drug combinations for marketing. The total ash of SM was found to be $4.76 \pm 0.08 \% \mathrm{w} / \mathrm{w}$. is reasonably low indicating low contamination. Water-soluble ash is the part of the total ash content, which is soluble in water. It is a good indicator of either previous extraction of water-soluble salts in the drug or incorrect preparation. Thus, it is the difference in weight between the total ash and the residue obtained after treatment of total ash with water. The acid insoluble and water-soluble ash values of SM were $3.36 \pm \mathbf{0 . 0 1} \%$ $\mathrm{w} / \mathrm{w}$ and $\mathbf{0 . 8 9} \pm \mathbf{0 . 2 5} \% \mathrm{w} / \mathrm{w}$ respectively. ${ }^{19}$ [Table 2] $\mathrm{pH}$ of SM in $1 \%$ solution was $\mathbf{6 . 6} \pm \mathbf{0 . 1}$ while the $\mathrm{pH}$ of $10 \%$ solution was $\mathbf{6 . 0} \pm \mathbf{0 . 1}$. [Table 2] It is slightly acidic in nature. The correlation between the $\mathrm{pH}$ and microbial contamination was studied by Abba et al. and suggested that a neutral or alkaline $\mathrm{pH}$ favours high microbial contamination levels of the herbal preparations. ${ }^{20}$ 
Table 5: Rf value, No. of Peaks, peak area and height of ethanolic extract of Safoof-e-Makhana (SM) in n-Butanol: Acetic acid: water at 254nm.

\begin{tabular}{ccccccccccc}
\hline Peak & Start $R f$ & Start Height & Max. $R \boldsymbol{f}$ & Max. Height & Max. \% & End $R f$ & End Height & Area & Area \% \\
\hline 1. & 0.24 & 0.0 & 0.25 & 12.2 & 2.01 & 0.28 & 1.7 & 185.5 & 0.76 \\
2. & 0.35 & 0.1 & 0.40 & 106.3 & 17.44 & 0.44 & 21.8 & 3351.1 & 13.72 \\
3. & 0.44 & 22.2 & 0.56 & 491.0 & 80.56 & 0.60 & 0.4 & 20888.3 & 85.52 \\
\hline
\end{tabular}

Table 6: $\boldsymbol{R f}$ value, No. of Peaks, peak area and height of ethanolic extract of Safoof-e-Makhana (SM) in n-Butanol: Acetic acid: water at $366 \mathrm{~nm}$.

\begin{tabular}{|c|c|c|c|c|c|c|c|c|c|}
\hline Peak & Start $R f$ & Start Height & Max. $R f$ & Max. Height & Max. \% & End $R f$ & End Height & Area & Area \% \\
\hline 1. & 0.08 & 2.6 & 0.11 & 78.0 & 8.40 & 0.13 & 22.9 & 1126.1 & 2.76 \\
\hline 2. & 0.14 & 22.9 & 0.14 & 24.7 & 2.66 & 0.18 & 6.9 & 511.1 & 1.25 \\
\hline 3. & 0.18 & 7.1 & 0.20 & 21.7 & 2.34 & 0.23 & 8.5 & 537.7 & 1.32 \\
\hline 4. & 0.32 & 8.3 & 0.33 & 12.5 & 1.35 & 0.34 & 1.0 & 118.6 & 0.29 \\
\hline 5. & 0.34 & 0.1 & 0.40 & 145.8 & 15.70 & 0.44 & 65.4 & 5536.5 & 13.59 \\
\hline 6. & 0.44 & 65.5 & 0.56 & 645.9 & 69.56 & 0.60 & 0.7 & 32910.4 & 80.78 \\
\hline
\end{tabular}

Table 7: Rf value, No. of Peaks, peak area and height of ethanolic extract of Safoof-e-Makhana (SM) in Toluene: Ethyl acetate: Formic acid at 254 nm.

\begin{tabular}{ccccccccccc}
\hline Peak & Start $R f$ & Start Height & Max. $R f$ & Max. Height & Max. \% & End $R f$ & End Height & Area & Area \% \\
\hline 1. & 0.49 & 2.3 & 0.52 & 14.8 & 6.99 & 0.54 & 10.2 & 319.5 & 5.51 & \\
2. & 0.57 & 18.4 & 0.60 & 41.9 & 19.75 & 0.60 & 40.0 & 679.6 & 11.72 \\
3. & 0.60 & 40.3 & 0.63 & 116.6 & 54.91 & 0.68 & 43.8 & 3553.8 & 61.30 \\
4. & 0.73 & 32.1 & 0.75 & 39.0 & 18.36 & 0.79 & 0.8 & 1244.2 & 21.46 \\
\hline
\end{tabular}

Table 8: $R f$ value, No. of Peaks, peak area and height of ethanolic extract of Safoof-e-Makhana (SM) in Toluene: Ethyl acetate: Formic acid at 366nm.

\begin{tabular}{ccccccccccc}
\hline Peak & Start $R f$ & Start Height & Max. Rf & Max. Height & Max. \% & End $R f$ & End Height & Area & Area \% \\
\hline 1. & 0.49 & 0.6 & 0.52 & 27.9 & 11.47 & 0.54 & 10.9 & 506.6 & 8.47 \\
2. & 0.56 & 15.3 & 0.60 & 38.6 & 15.90 & 0.61 & 35.7 & 926.7 & 15.50 \\
3. & 0.61 & 35.8 & 0.63 & 129.7 & 53.44 & 0.67 & 43.1 & 3488.6 & 58.34 \\
4. & 0.67 & 43.3 & 0.68 & 46.6 & 19.19 & 0.73 & 5.4 & 1057.7 & 17.69 \\
\hline
\end{tabular}

The mean percentage of water-soluble and alcohol soluble extractive values of Safoof-e-Makhana (SM) were $\mathbf{2 1 . 8 3 \pm 0 . 0 8}$ and $7.87 \pm 0.09$ respectively. The mean percentage of successive extractive values in petroleum ether, benzene, chloroform and ethyl alcohol were $\mathbf{1 1 . 4 7}$ $\pm \mathbf{0 . 1 7}, 0.57 \pm \mathbf{0 . 0 9}, 0.54 \pm \mathbf{0 . 0 5}$ and $2.27 \pm 0.09$ respectively. Nonsuccessive extractive values in petroleum ether, benzene, chloroform, ethyl alcohol and water were $11.69 \pm 0.11,9.02 \pm 0.05,9.55 \pm 0.04$, $\mathbf{1 2 . 9 0} \pm \mathbf{0 . 0 5}$ and $\mathbf{3 2 . 0 8} \pm \mathbf{0 . 0 6}$ respectively. [Table 3] Extractive value of a drug in definite solvent is an index for checking the purity of a drug. Amount of the extract of a drug in a particular solvent is often an appropriate measuring tool for certain constituent in the drug. ${ }^{21}$

Organic constituent's viz. alkaloids, glycosides, tannins, flavanoids, sugars, saponins, phenols, proteins, resins, steroids were found present on qualitative estimation tests. [Table 4]

HPTLC: HPTLC plates of ethanolic extract of Safoof-e-Makhana (SM) in two separate mobile phases viz. n-Butanol: Acetic acid: water (5:1:4) and Toluene: Ethyl acetate: Formic acid (5:4:1) were examined. $R f$ value, numbers of peaks, peak area and peak height of Safoof-e-Makhana (SM) in two separate mobile phases viz. n-Butanol: Acetic acid: water (5:1:4) Figure 2, 3, 4, 5, 6 and Toluene: Ethyl acetate: Formic acid (5:4:1) Figure $7,8,9,10$ and 11 were also analysed under $254 \mathrm{~nm}, 366 \mathrm{~nm}$ respectively. Area percentage of peak no. 3 of Safoof-e-Makhana (SM) analysed under $254 \mathrm{~nm}$ in n-Butanol: Acetic acid: water (5:1:4) was highest $(85.52 \%)$.
[Table 5] Area percentage of peak no. 3 of Safoof-e-Makhana (SM) analysed under 254nm in Toluene: Ethyl acetate: Formic acid (5:4:1) was highest (61.30\%).[Table 7] Area percentage of peak no. 6 of Safoof-eMakhana (SM) analysed under $366 \mathrm{~nm}$ in n-Butanol: Acetic acid: water (5:1:4) was highest (80.78\%). [Table 6] Area percentage of peak no. 3 of Safoof-e-Makhana (SM) analysed under $366 \mathrm{~nm}$ in Toluene: Ethyl acetate: Formic acid (5:4:1) was highest (58.34\%). [Table 8]

Further studies can be done by the help of standards for quantitative estimation and identification of the ingredients peak. Present HPTLC fingerprinting data can help in authentication and identification of Safoof-e-Makhana (SM) in the performed solvent system and extract.

Review of literature on ingredient of SM revealed promising constituent and pharmacological activity in it. Safoof ingredient such as Orchis latifolia contains many important constituents like glycosides, starch, albumin, volatile oil and bitter principles; Hygrophila auriculata contains alkaloids and fatty acids; ${ }^{22}$ Asparagus racemosus contains Sugar, Glycosides, Saponins and Sitosterol. ${ }^{23}$ Elettaria cardamomum contains Essential Oil. ${ }^{24}$ Reported activity of aqueous extract of Orchis latifolia are ameliorative and aphrodisiac activities tested in vivo, ${ }^{25}$ methanolic extract of Orchis latifolia shows anticandidal and antimicrobial activities tested in vitro. ${ }^{26}$ Reported activity of aqueous and methanolic extract of Hygrophila auriculata shows antimicrobial activity tested in vitro, ${ }^{27}$ alcoholic extract of Hygrophila auriculata shows antioxidant activity 


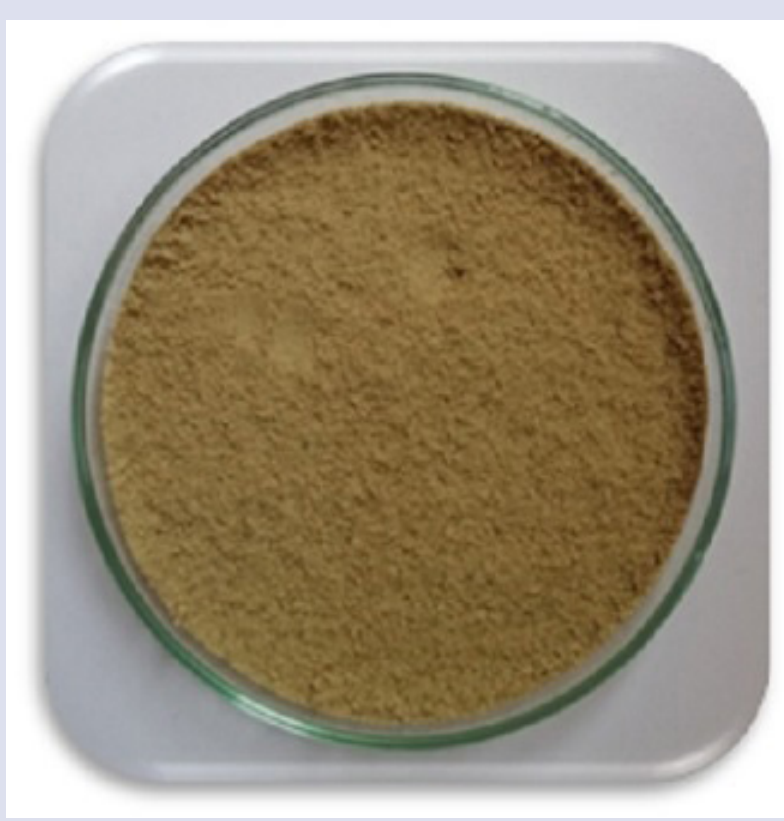

Figure 1: Safoof-e-Makhana.

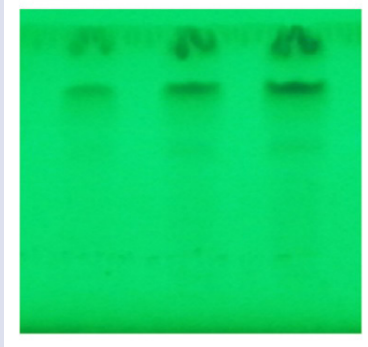

$254 \mathrm{~nm}$

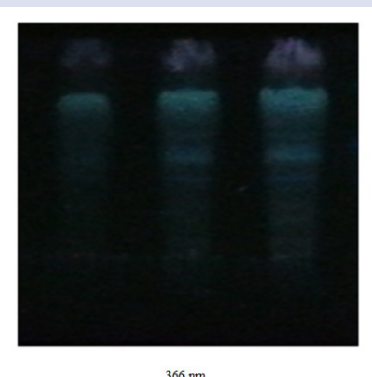

Figure 2: HPTLC photos of Safoof-e-Makhana (SM) ethanolic extract in n-Butanol: Acetic acid: water at $254 \mathrm{~nm}$ and $366 \mathrm{~nm}$.

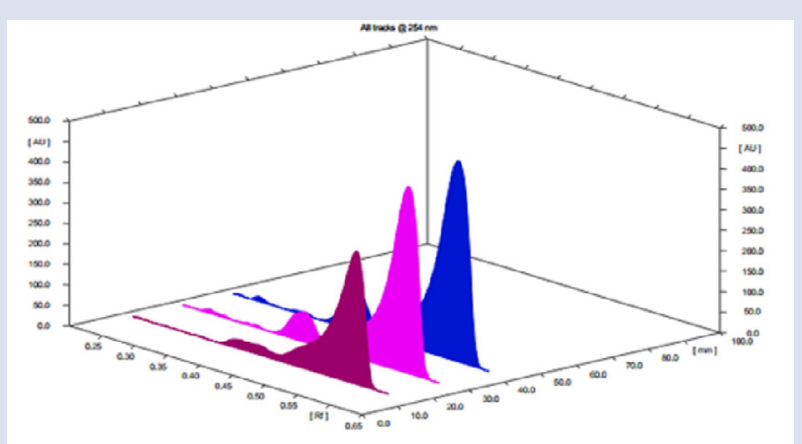

Figure 3: HPTLC 3-D Densitometric Scan of ethanolic extract of Safoof-e-Makhana (SM) in n-Butanol: Acetic acid: water at $254 \mathrm{~nm}$.

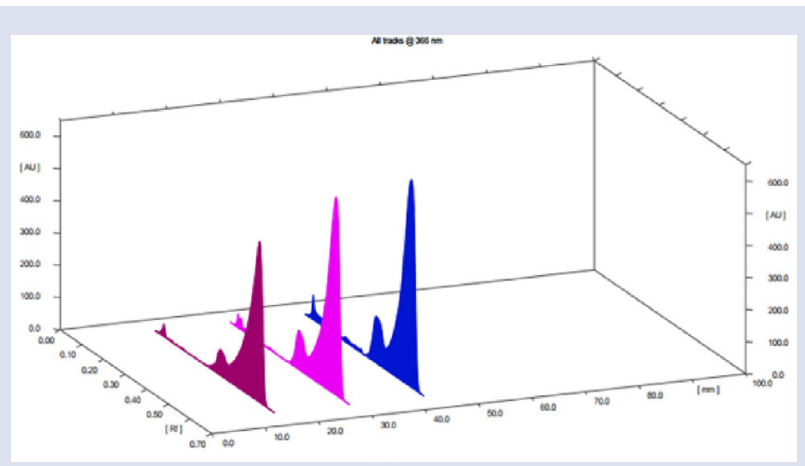

Figure 4: HPTLC 3-D Densitometric Scan of ethanolic extract of Safoof-e-Makhana (SM) in n-Butanol: Acetic acid: water at $366 \mathrm{~nm}$.

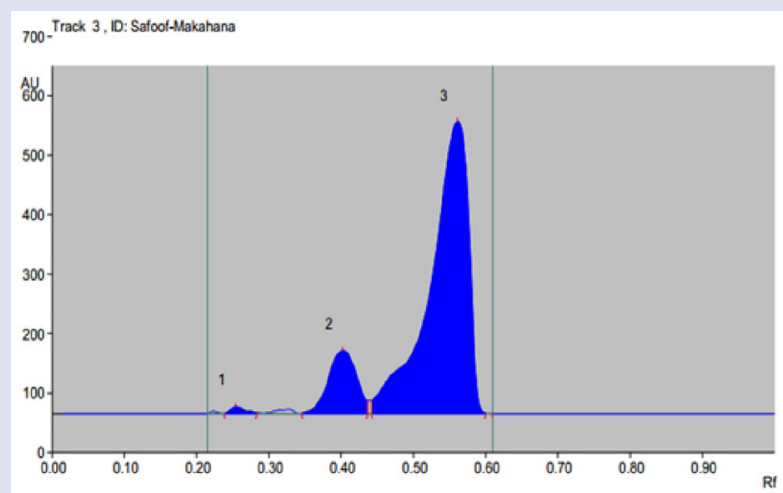

Figure 5: HPTLC fingerprint profile of ethanolic extract of Safoof-eMakhana (SM) in n-Butanol: Acetic acid: water at $254 \mathrm{~nm}$.

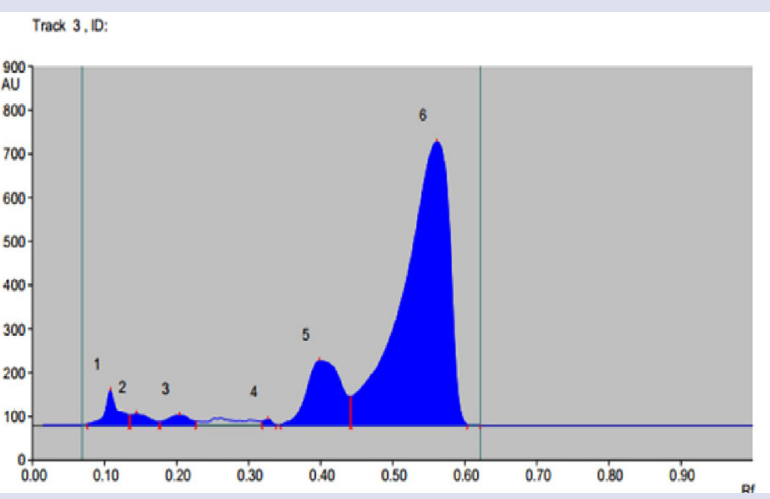

Figure 6: HPTLC fingerprint profile of ethanolic extract of Safoof-eMakhana (SM) in n- Butanol: Acetic acid: water at $366 \mathrm{~nm}$. 


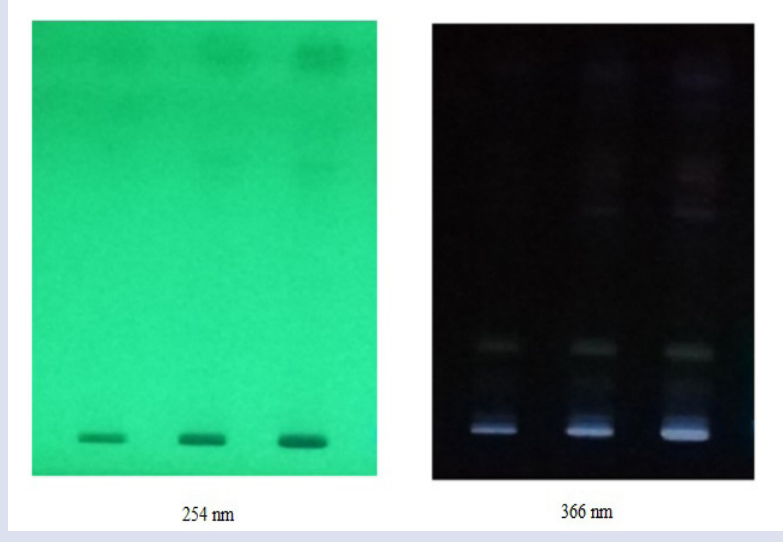

Figure 7: HPTLC photos of Safoof-e-Makhana (SM) ethanolic extract in Toluene: Ethyl acetate: Formic acid at $254 \mathrm{~nm}$ and $366 \mathrm{~nm}$.

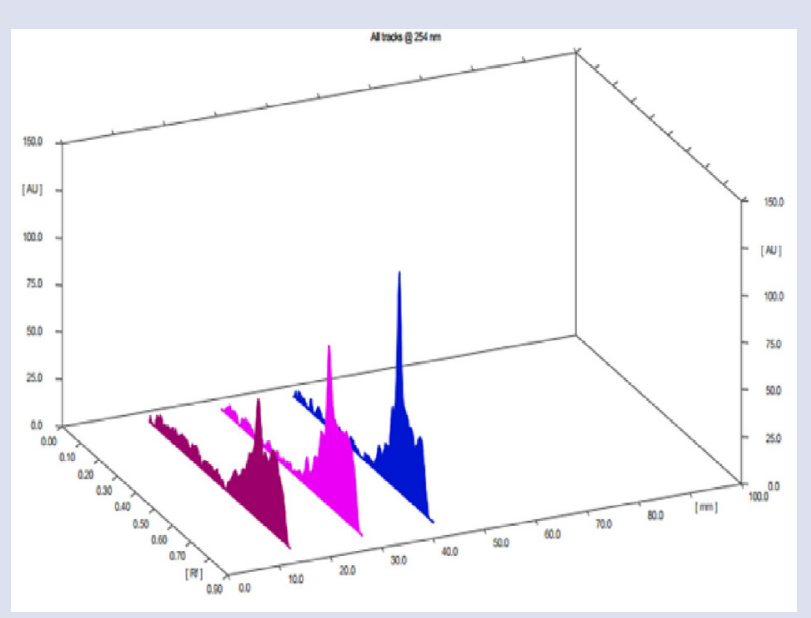

Figure 8: HPTLC 3-D Densitometric Scan of ethanolic extract of Safoof-e-Makhana (SM) in Toluene: Ethyl acetate: Formic acid at $254 \mathrm{~nm}$.

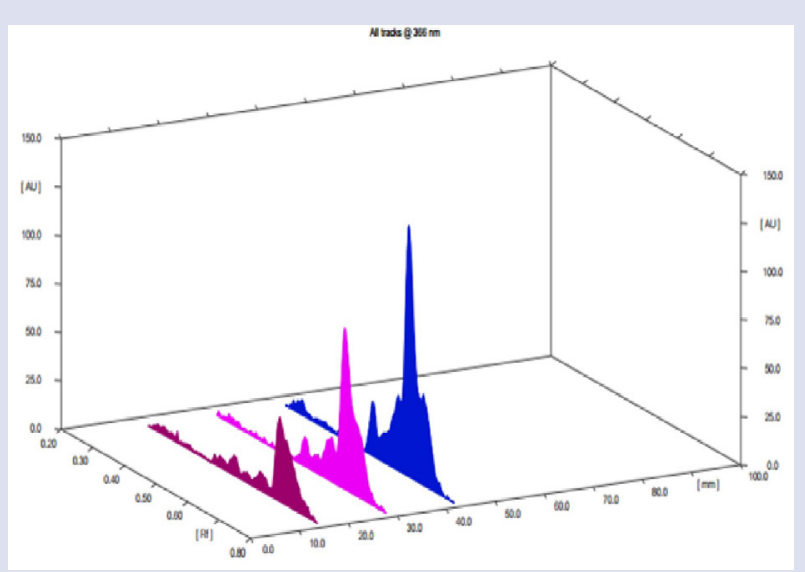

Figure 9: HPTLC 3-D Densitometric Scan of ethanolic extract of Safoof-e-Makhana (SM) in Toluene: Ethyl acetate: Formic acid at $366 \mathrm{~nm}$.

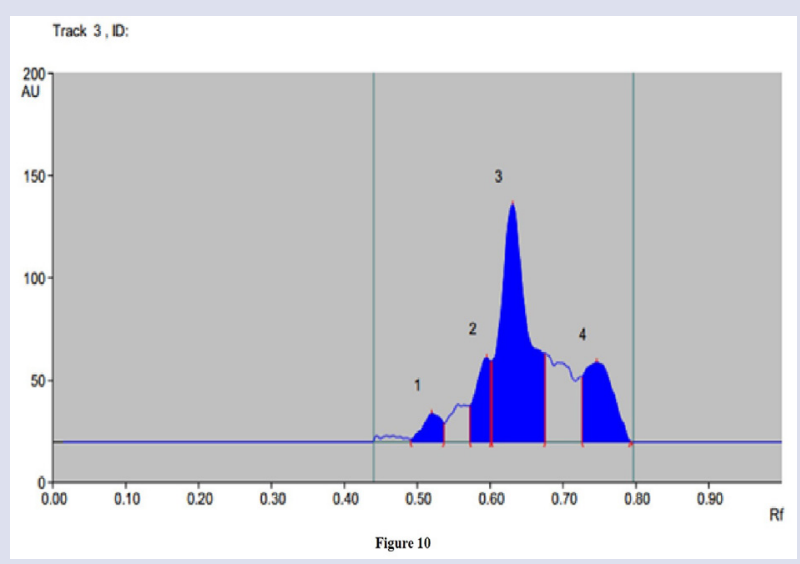

Figure 10: HPTLC fingerprint profile of ethanolic extract of Safoofe-Makhana (SM) in Toluene: Ethyl acetate: Formic acid at $254 \mathrm{~nm}$.

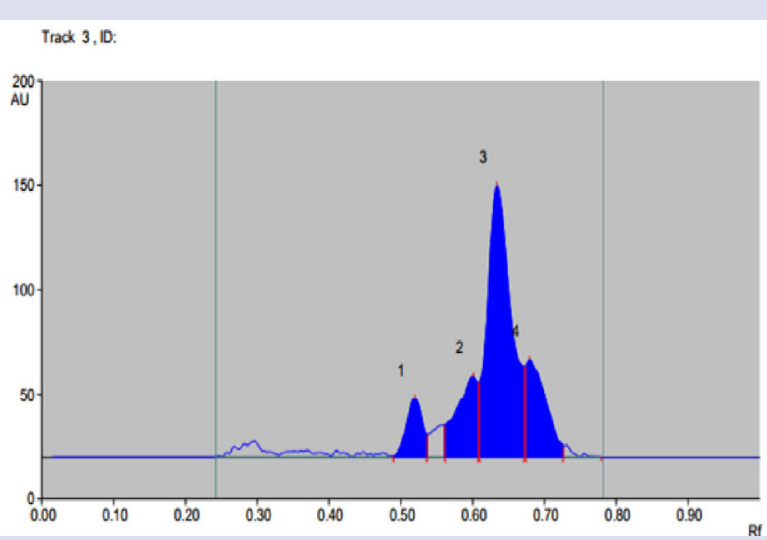

Figure 11: HPTLC fingerprint profile of ethanolic extract of Safoofe-Makhana (SM) in Toluene: Ethyl acetate: Formic acid at $366 \mathrm{~nm}$.

tested in vitro. ${ }^{28}$ Reported activity of hydroalcholic extract of Asparagus racemosus shows aphrodisiac activity tested in vivo, ${ }^{29}$ methanolic extract of Asparagus racemosus shows anti-oxidant and anti-ulcer activity tested in vivo. ${ }^{30}$ Reported activity of aqueous extract of Elettaria cardamomum shows antimicrobial activity tested in vitro, ${ }^{31}$ methanolic extract of shows anti-oxidant activity tested in vitro. ${ }^{32}$

The most important lacunae in alternative system of medicine for its globalization is difficulty to ensure uniformity and quality of drugs. Powder dosage form Safoof-e-Makhana (SM) doesn't have any pharmacopoeial standards since yet. Various methods and parameters for the assessment of powder dosage form are mentioned in different guidelines. It is necessary to follow these guidelines so that data can be generated and could be used to set the standards ofthe formulation. It can be used for quality control purpose to achieve maximum efficacy and safety of medicine.

\section{CONCLUSION}

In present study Safoof-e-Makhana (SM) was evaluated physico-chemically to set its physicochemical standards (loss of weight on drying, $\mathrm{pH}$, total ash, water soluble, acid insoluble ash, extractive values, qualitative data for presence of organic constituents and HPTLC finger printing), which may be used as standard monograph for identification and quality 
control and also further evaluation or future research work on standardization of this formulation.

\section{ACKNOWLEDGEMENT}

The authors would like to express their thanks to Prof. M.A Siddiqui, Director, National Institute of Unani Medicine (NIUM) Bangalore, for providing all the essential assistant and motivation to work and to Dr. Nagraaj, HoD, Department of Pharmaceutical Analysis PES college of Pharmacy Bangalore for HPTLC work.

\section{CONFLICT OF INTEREST}

There are no conflicts of interest.

\section{ABBREVIATIONS}

WHO: World Health Organisation, USM: Unani System of Medicine, SM: Safoof-e-Makhana, HPTLC: High Performance Thin Layer Chromatography, SEM: Standard Error of Mean; LOD: Loss on Drying; UPI: Unani Pharmacopeia of India; ASU: Ayurveda, Siddha and Unani; TLC: Thin Layer Chromatography.

\section{REFERENCES}

1. Satheesh NV, Kumud U, Asha B. Phytochemical screening and standardization of poly herbal formulation for Dyslipidemia. International Journal of Pharmacy and Pharmceutical Science 2011;3(3):235-38.

2. De La Sante OM. Quality control methods for medicinal plant materials, 559, rev.1, Original English, World Health Organisation.1992:159.

3. Sriwastava NK, et al. Standardization of Ajmodadi churna, a polyherbal formulation. Pharmacognosy Research. 2010;2(2):98-101.

4. Anonymous, National Fromulary of Unani Medicine, Government of India Ministry of Health and Family Welfare (Department of AYUSH), New Delhi. 2011:105.

5. Protocol for Testing of Ayurveda, Siddha, Unani Medicine, Govt. of India Deptt. Of AYUSH Ministry of Health and Family Welfare, Pharmacopeial Laboratory for Indian Medicine Ghaziabad. 2007;40:49-50.

6. Beringer $P$, et al. 'Remington the Science and Practice of pharmacy', Lippincott, 21st Edition, Vol I. 2006:712.

7. Anonymous, World Health Organization, Bulk Density and Tapped Density of Powders. Document QAS/11.450 FINAL Geneva. 2012;1-6. Available at URL: http://www.who.int/medicines/ publications/ pharmacopoeia/ Bulk-tapped-density, accessed on 13-2-18.

8. The Unani Pharmacopoeia of India. Part II Vol.II, First edition. New Delhi: Govt. of India. Ministry of Health and Family Welfare, Dept. of AYUSH. 2010;2:158-9.

9. Physicochemical standardization of Unani formulations. Part IV. New Delhi; CCRUM, Ministry of Health and Family Welfare, Govt. of India. 2006;142$145,157-160$

10. Ali W, Shaikh H, Ansari A, Khanam S. Standardization of Unani Antidiabetic Tablet - Qurse Tabasheer. Pharmacognosy Research. 2016.8(2):147-52.

11. Mukhi S, Bose A, Panda P, Rao MM. Pharmacognostic, physicochemical and chromatographic characterization of Samasharkara Churna. Journal of Ayurveda and Integrative Medicine. 2016;7(2):88-99

12. Vaidya ADB, Devasagayam TP. Current status of herbal drugs in India: An overview. J Clin Biochem. 2007;41(1):1-11.

13. Yadav NP, Dixit VK. Recent approaches in herbal drug standardization. Int $J$ Integr Biol. 2008;2(3):195-203.

14. Pantone Colour Chart. http://www.american powder.com/colorchart, field color chart and field color family. Accessed on 09-02-18.

15. Emery E. Flow Properties of Selected Pharmaceutical Powders. Saskatchewan, University of Saskatchewan. 2008:9-10.

16. The United States Pharmacopeial Convention. USP32-NF27. The Institute, Toronto. 2009:618-706. [Cited on 02-02-18]. Available at URL: http:// www. pharmacopeia. cn/v 29240 /usp 29 nf 24 s 0 _c 1191.html.

17. Vyas SP, Amit K, Goyal AK, Rath G. Handbook of pharmaceutical dosage forms, Vallabh Prakashan, Delhi, Ist edn. 2011:135-7.

18. Júnior JO, Costa RM, Teixeira FM, Barbosa WL. Processing and Quality Control of Herbal Drugs and Derivatives. In: Shoyama Y. (ed) Quality Control of Herbal Medicines and Related Areas. In Tech, Brazil. 2011;211.

19. Chandel HS, Pathak AK, Tailang M. Standardization of some herbal antidiabetic drugs in polyherbal formulation. Pharmacognosy Research. 2011;3(1):49-56.

20. Abba D, Inabo HI, Yakubu SE, Olonitola OS. Contamination of Herbal Medicinal Products Marketed in Kaduna Metropolis with Selected Pathogenic Bacteria. Afr J Tradit Complement and Altern Med. 2009;6(1):70-7.

21. Jahan N, Afaque SH, Khan G, Ansari AA. Physicochemical studies of the Gum acacia. Nat Prod Radiance. 2008;7:335-7.

22. The Unani Pharmacopeia of India, Government of India Ministry of Health and Family Welfare Department of AYUSH, New Delhi, Part-I, Vol. III. 2007;3:88-9.

23. The Unani Pharmacopeia of India. Government of India Ministry of Health and Family Welfare Department of AYUSH, New Delhi, Part-I, Vol. VI. 2009;4:74-5.

24. The Unani Pharmacopeia of India, Government of India Ministry of Health and Family Welfare Department of AYUSH, New Delhi, Part-I, Vol. I. 2007;1:34-5.

25. Thakur M, Dixit VK. Ameliorative effect of fructo-oligosaaharide rich extract of Orchis latifolia on erectile dysfunction in hyperglycemic male rats. Sex Disability. 2008:26(1):37-46.

26. Anupama SA, Ghosal S, Purkayastha SH. Study of Antimicrobial Activity of Orchis Latifolia. Int J Pharm Bio Sci. 2013;4(4):638-46

27. Nigam V, Mishra RK, Gupta A, Kumar M. Pharmacognostic Study, Characterization of Marker Compounds and Pharmacological Review of Aerial Parts of Hygrophila Auriculata (Schumach.) Heine. World Journal of Pharmacy and Pharmaceutical Sciences. 2015:4(12):1127-43.

28. Hussain MS, Ahamed KH, Ravichandiran V, Ansari MZ. Evaluation of In vitro Free Radical Scavenging Potential of Different Fractions of Hygrophila Auriculata / Asian Journal of Traditional Medicines. 2009;4(5):179-87.

29. Wani JA, Achur RN, Nema RK. Phytochemical Screening and Aphrodisiac Activity of Asparagus. International Journal of Pharmaceutical Sciences and Drug Research. 2011;8(9):112-5.

30. Bhatnagar M, Sisodia SS, Bhatnagar R. Antiulcer and antioxidant activity of Asparagus racemosus Willd and Withania somnifera Dunal in rats. Ann NY Acad Sci. 2005;1056(1):261-78.

31. Jebur MH, Dr. Bnuyan I, Dr. Yasri AA, Dr. Hindi NK. Antimicrobial Effect of Seed Extracts, Leaves and Crude Oil of Cardamom (Elettaria cardamomum) Against Different Types of Bacteriain Hilla City, Iraq. World Journal of Pharmaceutical Research. 2017;3(3):4934-44.

32. Amma KP, Rani MP, Sasidharan I, Nisha VN. Chemical composition, flavonoidphenolic contents and radical scavenging activity of four major varieties of car damom. International Journal of Biological and Medical Research. 2010;1(3):20-4

\section{GRAPHICAL ABSTRACT}

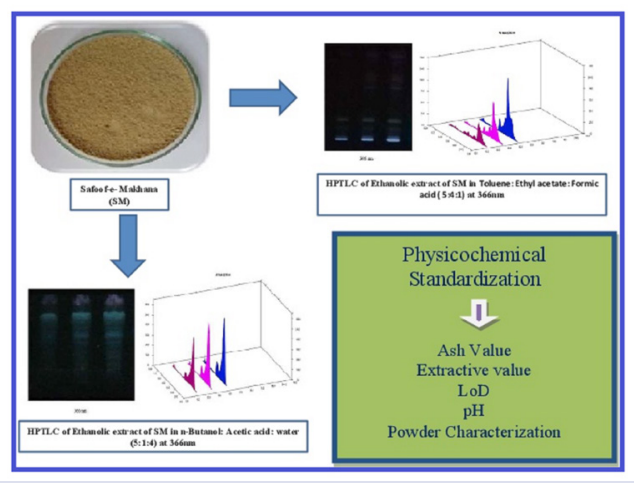

\section{SUMMARY}

- Standardization data of Safoof-e-Makhana (SM), a Unani pharmacopoeial Powder formulation composed of Orchis latifolia, Hygrophila auriculata, Asparagus racemosus and Elettaria cardamomum by various physicochemical parameters was established

- $\quad$ HPTLC analysis was performed and HPTLC figure printing data of ethanolic extract of SM in n-Butanol: Acetic acid: water (5:1:4) and Toluene: Ethyl acetate: Formic acid (5:4:1) were set in. 


\section{ABOUT AUTHORS}

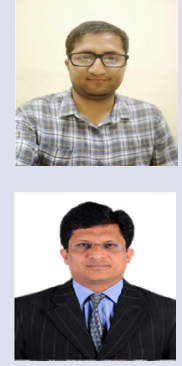

Dr Gazi Jahangeer Rather (PG Scholar Dept. of IImul Saidla, National institute of Unani Medicine)

Dr Hamiduddin MD (U) IImul Advia (Pharmacology) working as a Lecturer, Dept. of IImul Saidla (Uanani Pharmacy) National Institute of Unani Medicine, Bangalore, an autonomous organization under Min. of AYUSH, Govt. of India

Dr Mohd Ikram (PG Scholar, Dept. of IImul Saidla, National institute of Unani Medicine )

Dr Shaista Fatima (PG Scholar Dept. of Ilmul Saidla, National institute of Unani Medicine )

Dr MD Naquibuddin (PG Scholar Dept. of IImul Saidla, National institute of Unani Medicine )

Cite this article: Rather GJ, Hamiduddin, Ikram M, Fatima S, Naquibuddin MD. Physicochemical Standardization of Polyherbal Powder Formulation: Safoof-e-Makhana. Pharmacog J. 2018;10(5):899-906. 